\title{
CALIDION BOMBACIS, A NEW COMBINATION FOR UREDO BOMBACIS WITH THE RECORD OF BOMBACOPSIS GLABRA (BOMBACACEAE) AS A NEW HOST FROM BRAZIL
}

\author{
Meiriele da Silva'; Dartanhã José Soares ${ }^{2 *}$; Robert Weingart Barreto ${ }^{1}$ \\ ${ }^{1}$ Departamento de Fitopatologia, Universidade Federal de Viçosa, Viçosa, MG, Brasil; ${ }^{2}$ EMBRAPAAlgodão, Campina Grande, \\ PB, Brasil
}

Submitted: September 20, 2007; Returned to authors for corrections: September 18, 2008; Approved: February 14, 2009.

\begin{abstract}
The new combination Calidion bombacis is proposed for the rust species formerly known as Uredo bombacis. This nomenclatural change is based on the examination of newly collected material of this fungus from a new host, Bombacopsis glabra from Brazil, and reexamination of the isotype. Until now this fungus was only known to occur in Asia (China, India and Sri Lanka). Therefore, this is also the first record of this fungus from the Neotropics.
\end{abstract}

Keywords: Bombax malabaricum, Chrysomyxa bombacis, Pachira glabra, Puccinia bombacis, rust fungi, Uredinales.

Bombacopsis glabra (Pasq.) A. Robyns [Bombacaceae sensu Mabberley (7) and Heywood et al. (5)], is a fast-growing small tree native from Brazil where it is known by the local names: castanha-do-maranhão, castanha-da-praia, cacau-do-maranhão, among others. It is indigenous to the Atlantic Tropical Rainforest of Brazil, occurring mainly along the coast from the state of Pernambuco to Rio de Janeiro. It is sometimes used as an ornamental urban tree, planted in hedges of the coastal areas of Brazil and it also produces edible nuts (6).

In August 2006, leaves of B. glabra showing typical rust symptoms were collected in the campus of the Universidade Federal de Viçosa (state of Minas Gerais, Brazil). The presence of a rust fungus was confirmed after examination of samples under a dissecting microscope. Free-hand sections of diseased leaf tissue bearing rust pustules were prepared and mounted in lactophenol. Slides were then examined with an Olympus BX 51 microscope fitted with a digital camera (Olympus E-330). A representative sample was dried in a plant press and deposited in the local herbarium (Herbarium VIC). Morphology of the fungus was examined and fited well with the description of Uredo bombacis Petch. The newly collected material was compared with the isotype and, as discussed below, a new combination was found to be necessary under the current morphological concept for the uredinial anamorphs of rust fungi (1). The new combination and a description based on the Brazilian specimen are presented below.

Calidion bombacis (Petch) D.J. Soares and R.W. Barreto comb. nov. MycoBank 511165 (Figs. 1-7).

$\equiv$ Uredo bombacis Petch, Ann. Roy. Bot. Gard. (Peradeniya) 5:247.

Symptoms characterized by irregular necrotic lesions, mostly punctiform, both in young and mature leaves, usually partly vein-delimited, dark-brown to black adaxially, light brown to brown abaxially, $0.3-1.7 \times 0.2-1.0 \mathrm{~mm}$, rarely coalescencing. Urediniosorus mostly hypogenous, isolate, erumpent, irregular, 34.5-97.5 $\mu \mathrm{m}$ diam., grey to yellowish. Paraphyses single or in fascicle, mainly concentrated at the edges of sori, falcate to strongly curved, aseptate (rarely one-septate), 6.5$7.5 \mu \mathrm{m}$ diam., walls $1.0-1.5 \mu \mathrm{m}$ thick, hyaline to light brown. Urediniospores mainly ovoid, subglobose to ellipsoid, 17.5$37 \times 14.5-28 \mu \mathrm{m}$, subhyaline to yellowish-brown, walls $0.5-1.5$ $\mu \mathrm{m}$ thick, medium to strongly equinulate $(0.5-1.5 \mu \mathrm{m})$, germpores indistinct.

Material examined: on Bombacopsis glabra (Pasq.) A. Robyns (Bombacaceae), Silvicultura, Campus Universidade Federal de Viçosa, Viçosa, state of Minas Gerais, Brazil (VIC

*Corresponding Author. Mailing address: Departamento de Fitopatologia, Universidade Federal de Viçosa, 36571-000, Viçosa, Minas Gerais, Brasil. E-mail: dartjs@yahoo.com.br 

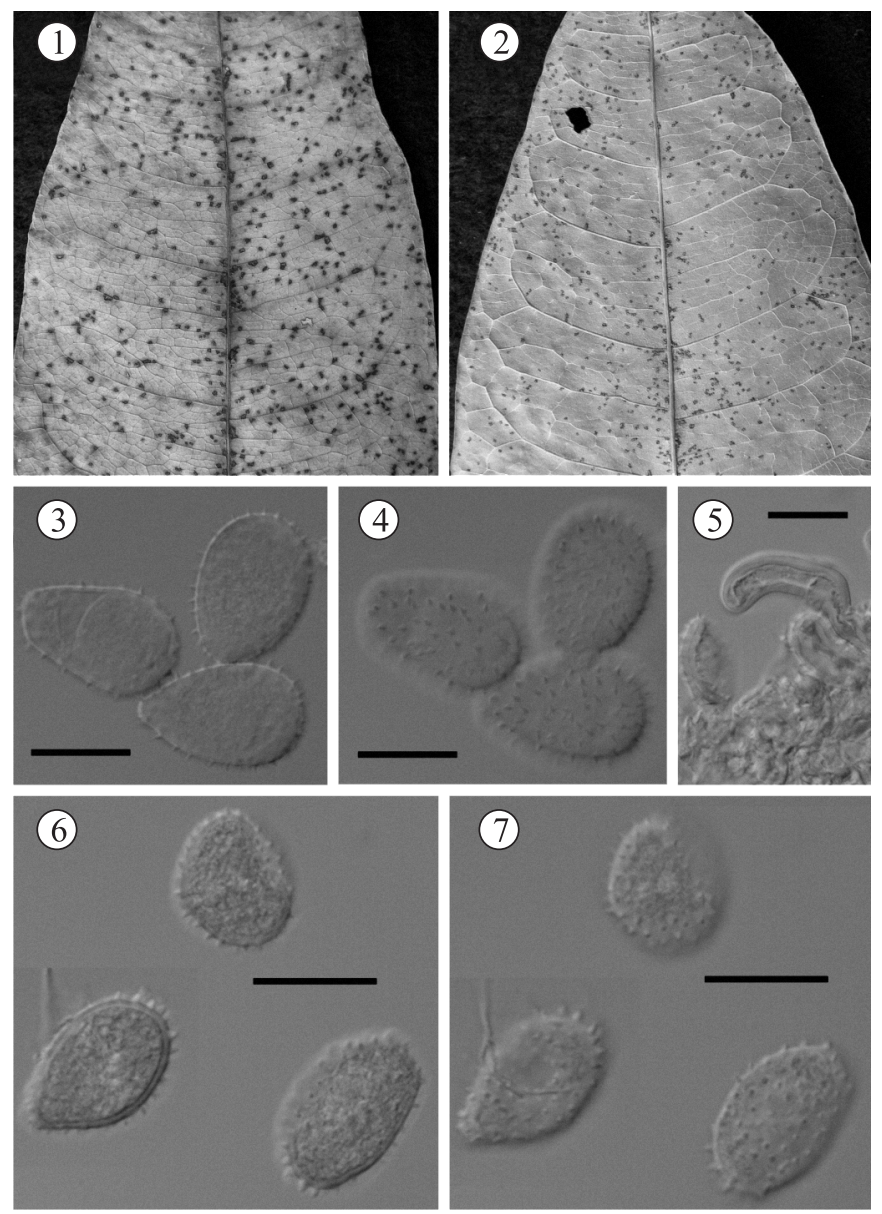

Figures 1-7. Halftones photomicrographs of Calidion bombacis. 1-2. Symptoms on B. glabra showing dark-brown to black punctiform lesions in the adaxial (1) and abaxial (2) leaf side; 3-4. Median (3) and superficial view of the urediniospores ex B. glabra; 5. A peripheral thick-walled paraphysis ex B. glabra; 6-7. Median (3) and superficial view of the urediniospores ex type (BR-MYC 77905). Bars $=10 \mu \mathrm{m}$.

30462). On Bombax malabaricum DC, Peradeniya, Sri Lanka (BR-MYC 77905).

Comments - In Petch's original description (8), urediniospores size of $U$. bombacis given was: 16-28 x 12-18 $\mu \mathrm{m}$. However in ours re-examination of the type specimen we found uredioniopores with 17.5-31.5 x 14.5-20 $\mu \mathrm{m}$. The material of $B$. glabra from Brazil has a very similar morphology to that of the type specimen of $U$. bombacis (BR-MYC 77905, 14; 12 Dec 1911, Sydow Fungi Exotici Exsiccati no 116). One of the differences was a slight discrepancy in urediniospores size that was somewhat bigger (18-37 x 16-27 $\mu \mathrm{m})$ in our specimen. Another difference was the presence of distinct spots on the Brazilian specimen, while the type specimen has no evident spots. These minor differences were not regarded as being strong enough to separate this fungus from $U$. bombacis.

At present only three rust fungi are known to occur associated with members of the Bombacaceae: Chrysomyxa bombacis Petch, Puccinia bombacis Dietel and Uredo bombacis Petch (3). An attempt was made to reexamine the type specimens of all rust species on the Bombacaceae but, unfortunately we were unable to trace the type of $C h$. bombacis.

Puccinia bombacis was described by Dietel on Bombax sp. from Colombia and according to this author only the teleomorph was present (10). Chysomyxa bombacis and $U$. bombacis were described by Petch from the same host (Bombax malabaricum DC) and same locality (Peradeniya, Sri Lanka), but in different years $(8,9)$. Apparently the connection between these two states was not proven or even suggested by Petch.

Uredinial stages of fungi placed in the genus Chrysomyxa belong to the anamorphic genus Caeoma (1). Reexamination of the type specimen of $U$. bombacis confirmed that it does not belong to the genus Caeoma. Therefore, we agree with Petch in not recognizing this taxon as a stage in the life cycle of $C h$. bombacis.

Nevertheless, reexamination of the type specimen of $C h$. bombacis is necessary to elucidate the somewhat puzzling situation regarding the presence of such purportedly independent rust stages at the same host and same locality. Although possible, such an occurrence of independent stages of separate rust species from the same host at the same location appears somewhat intriguing. Additionally, in the original description by Petch he mentioned that Ch. bombacis has eightcelled teliospores, however according to Cummins and Hiratsuka (1) Chrysomyxa has one-celled, catenulate teliospores. Likewise, U. bombacis apparently cannot be connected with $P$. bombacis because this fungus is very likely to be a microcyclic species. Our carefull examination of all specimens of $P$. bombacis available at BPI and NY [BPI 050885; BPI 050886; BPI 050887; BPI 050888; BPI 852030; NY 00049146; NY 00049147 (Isotype)] confirmed that only telia are present in such materials.

After a detailed examination of the type specimen of $U$. bombacis and taking into consideration the probable lack of connection with $C h$. bombacis and $P$. bombacis, as well as the presence of strongly curved and thick-walled paraphyses and indistinct germ-pores, even when mounted in cotton blue or lactofuchsin, we decided that $U$. bombacis would be better placed in the genus Calidion H. \& P. Syd, following the morphological concepts adopted by Cummings and Hiratsuka (1). The genus Calidion was erected to accommodate an anamorphic rust fungus known only on ferns, however it is now recognized also as the anamorphic stage of Crossopsora, Olivea, Phragmidium, Prospodium, among others (1).

The present status for the rust fungi on the Bombacaceae is as follows: among the three supposedly separate species, $C h$. bombacis is known only from Sri Lanka on B. malabaricum (9); 
P. bombacis is known from Colombia occurring on Bombax sp. (2). Additionally another Puccinia sp. (possibly P. bombacis) was recorded on Pochota trinitensis (Urb.) Steyerm. \& W.D. Stevens and Pseudobombax septenatum (Jacq.) Dugand from Venezuela (3). Unfortunately no herbarium specimen was indicated for any of those records. A Puccinia sp. was also found on an undetermined Bombacaceae specimen from Peru, intercepted in Honolulu, Hawaii. Calidion bombacis was recorded (as $U$. bombacis) from Sri Lanka, India and China, on B. malabaricum $(8,11,12)$ and is reported here, for the first time, on B. glabra from Brazil. It represents the first record of a rust fungus in a member of the Bombacaceae in Brazil (4) and also the first record of $\mathrm{Ca}$. bombacis outside Asia.

\section{ACKNOWLEDGEMENTS}

The authors are thankful to Dr. Joost Stalpers for providing relevant information used in the discussion and to BPI, BR and NY herbaria for loan of the fungal specimens. Financial support from the $\mathrm{CNPq}$ (Conselho Nacional do Desenvolvimento Científico e Tecnológico) and FAPEMIG (Fundação de Amparo à Pesquisa do Estado de Minas Gerais) is acknowledged.

\section{RESUMO}

Calidion bombacis, uma nova combinação para Uredo bombacis e o relato de Bombacopsis glabra (Bombacaceae), como um novo hospedeiro no Brasil

A combinação nova Calidion bombacis é proposta para a ferrugem anteriormente conhecida como Uredo bombacis. Esta modificação nomenclatural é proposta baseada no exame de material deste fungo coletado em um novo hospedeiro, Bombacopsis glabra (Bombacaceae) no Brasil e reexame do isotipo. Até então este fungo tinha sido relatado apenas na Ásia (China, Índia e Sri Lanka). Portanto, este é o primeiro relato deste fungo nos Neotrópicos.

Palavras-chave: Bombax malabaricum, Chrysomyxa bombacis, ferrugens, Pachira glabra, Puccinia bombacis, Uredinales.

\section{REFERENCES}

1. Cummins, G.B.; Hiratsuka, Y. (2003). Illustrated genera of rust fungi. Third ed. APS Press, St. Paul, MN.

2. Dennis, R.W.G. (1970). Fungus Flora of Venezuela and Adjacent Countries. Kew Bulletin Additional Series III. Verlag von J. Cramer, Kew, UK.

3. Farr, D.F.; Rossman, A.Y.; Palm, M.E.; McCray, E.B. (n.d.). Fungal databases, systematic botany \& mycology laboratory, ARS, USDA Available at: http://nt.ars-grin.gov/fungaldatabases/. Accessed June 132007.

4. Hennen, J.F.; Figueiredo, M.B.; Caralho Jr, A.A.; Hennen, P.G. (2005). Catalogue of the species of plant rust fungi (Uredinales) of Brazil. Available at: http://www.jbrj.gov.br/publica/uredinales/Brazil Catalogue1drevisado.pdf . Accessed August 302007.

5. Heywood, V.H.; Brummitt, R.K.; Culham, A.; Seberg, O. (2007). Flowering plants families of the world. Firefly Books, Ontario, Canada.

6. Lorenzi, H. (1992). Árvores Brasileiras: manual de identificação e cultivo de plantas arbóreas nativas do Brasil. Editora Platarum, Nova Odessa, SP.

7. Mabberley, D.J. (2002). The Plant-Book: a portable dictionary of vascular plants. Second ed. Cambridge University Press. Cambridge, UK.

8. Petch, T. (1912). Ustilagineae and Uredineae of Ceylon. Ann. Roy. Bot. Gard. (Peradeniya) 5: 223-256.

9. Petch, T. (1917). Additions to Ceylon fungi. Ann. Roy. Bot. Gard (Peradeniya) 6 (3): 195-256.

10. Saccardo, P.A. (1902). Sylloge Fungorum XVI: 276

11. Sarbhoy, A.K.; Lal, G.; Varshney, J.L. (1971). Fungi of India (196771). Navyug Traders, New Delhi.

12. Zhuang, W.Y. (2001). Higher Fungi of Tropical China. Mycotaxon, Ltd., Ithaca, NY. 